\title{
Technological change and the Tragedy of the Commons: The Lofoten Fishery over Hundred and Thirty Years *
}

\author{
Rögnvaldur Hannesson \\ Department of Economics \\ The Norwegian School of Economics and Business Administration \\ rognvaldur.hannesson@nhh.no
}

Kjell G. Salvanes

Department of Economics

The Norwegian School of Economics and Statistics Norway, Center for the Economics of Education (CEP) and IZA

kjell.salvanes@nhh.no

\author{
Dale Squires \\ Southwest Fisheries Center \\ La Jolla, California \\ Dale.Squires@noaa.gov
}

February 212009

\begin{abstract}
Why did the Lofoten cod fishery in Norway, a fishery on one of the world's richest spawning grounds, remain less productive than alternative industries for about a hundred years, despite important modernization of the fleet and fishing gear, improvements in technology and institutional change? In the 1960s the fishery took a big leap forward. We analyze the effect of technological change on labor and total factor productivity, using detailed data for 130 years. Our findings support the important role of natural resources in productivity and improvements in welfare in natural resource-based industries. The total factor productivity has risen faster than labor productivity in the fishery, indicating that the considerable technological progress in this industry has to some extent been neutralized by the decline in the fish stock. Open access to the fish resource most probably led to this situation.
\end{abstract}

\footnotetext{
${ }^{*}$ We thank Ola Grytten, The Norwegian School of Economics and Business Administration, for access to data on wages for the manufacturing and agricultural industry in Norway.
} 


\section{Introduction}

A received wisdom in economics is that new knowledge and technological change is the only source of growth and improved welfare. How does this play out in industries based on common natural resources? The ongoing discussion about improvements in fishing technology threatening fish stocks indicates that the fruits of technological progress might not materialize in such industries.

Our point of departure is the puzzle raised by the low productivity of a resource based industry over 130 years; the Lofoten cod fishery. This fishery, taking place on one of the world's most productive spawning grounds, had several major occurrences of technological change over this period, and yet labor productivity remained low for a long time, lagging behind productivity development in agriculture and manufacturing over most of the period. ${ }^{1}$ How could this be?

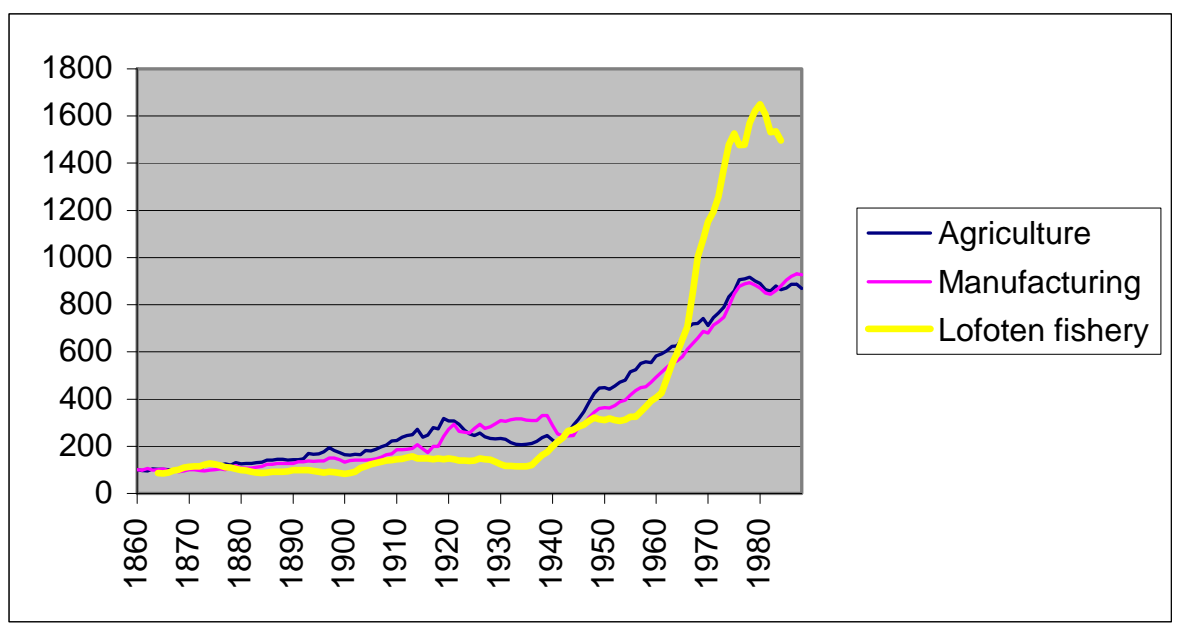

Figure 1: Indices of wages in agriculture and manufacturing, and 9-years moving average of revenues per fisherman.

Figure 1 shows the development of wages in agriculture and manufacturing, as well as the value of the catch per fisherman (9-years moving average). Except for two brief periods (around 1870 and in the 1940s), revenues per fisherman lagged behind wages in agriculture and manufacturing until the mid-1960s, when they took a big leap

\footnotetext{
${ }^{1}$ We do not have absolute values for productivity in agriculture and industry, only indices. Hence, what we can state unambiguously is that productivity grew more slowly in the Lofoten fishery than in the two other industries we compare with.
} 
forward. Comparing the 1970s and 80s with the 1860s, fishermen did better than keep pace with agriculture and manufacturing, even allowing for some decline in their share of revenues. Understanding this lack of improvement, even with important changes in technology, and then the big leap in productivity, is of interest not only for this industry but also for similar situations in other resource based industries.

Our main strategy for analyzing the effect of technological and institutional change on the development of productivity in the Lofoten fishery is to focus on the interaction between technological and institutional change in this fishery over 130 years and the natural resource on which it was based. The theory of open access natural resources tells us that they will be overexploited and that labor productivity of the associated industries will be on par with comparable occupations. It also tells us that people will flock into such industries as occupations of last resort if opportunities in the labor market dry up, a process that in the end is likely to be self-defeating and to make a negligible and possibly negative contribution to the total wealth of the economy. We will analyze this issue in the Lofoten fishery by estimating productivity measures of the fishery, especially comparing labor productivity to total factor productivity in order to identify the role of the natural resource.

The most likely explanation of the lack of productivity gain in the Lofoten fishery over 100 years is the fact that this was an open access industry. But so it remained for the entire period which we analyze (1860-1988). There are two possible and not mutually exclusive reasons for the leap in productivity after the Second World War. Many minor changes in technology could have come together and begun working in unison (Clark, 2007). Large boats, decked boats, engines, better equipment etc. are not enough separately, but when all of the changes that had taken place could be combined, as they were in the 1950s, progress in productivity was possible. The other explanation is the rapid economic growth in the Norwegian economy since the mid-20 $0^{\text {th }}$ Century. This provided better outside opportunities and is likely to have absorbed those who were least skilled at fishing and had the least effective boats. By that time fishing was no longer an occupation of last resort.

Even if an open access resource industry appears stagnant in terms of productivity, technology could still be progressing at a rate comparable to other 
industries, with its fruits rotting away as it were through overexploitation of the fish stock. To examine this we will calculate total factor productivity, with the fish stock as a factor of production in addition to labor and boats. This concept is analogous to total factor productivity in other industries with one exception; high total factor productivity in the fishery does not necessarily make anyone better off. Total factor productivity might grow in the fishery, and yet the total production of fish might decline for any given input of factors under human control, due to a declining fish stock. In an ordinary manufacturing industry, rising total factor productivity is good news because production can be maintained despite less use of labor and capital, making it possible to share the value produced among fewer people working and provide a higher return to the owners of capital. In addition the labor released and the capital no longer needed could be used for other purposes, making the whole economy better off. But decline of fish stocks has no such effects. A declining fish stock does not mean that more fish become available for some purpose other than fishing; a declining fish stock is likely to put an upward pressure on the cost of each fish caught and will ultimately reduce the surplus growth of the stock, which sets the limits for sustainable fishing. Growth in total factor productivity in the fishery while fish stocks decline would indicate that the fishing technology is progressing well, but it would not necessarily result in larger or cheaper fish catches. Hence, taking the role of fish stocks for productivity into account could explain what the technological development in the industry really is, whether or not it is comparable to other industries, and why it might be that technological progress in the fishery would not translate into larger fish catches and higher wages for fishermen.

The Lofoten fishery has a long history. It is mentioned in Egil's Saga, which deals with events that took place in the 800s AD. Later, dried fish (stockfish) from Lofoten was a major item of trade for the Hanseatic League and the reason for their trading post in Bergen, which lasted for hundreds of years. It was an important source of income-or a gamble to bet on-even for people from distant parts of Norway and still attracts fishermen from afar. For hundreds of years it was by far the most important fishery in Norway and indeed one of the most important sectors of the economy; as late as 1920 about 20,000 men stated fishing as their main occupation, compared to 90,000 farmers (Norwegian census, 1920). The fishery exploits the annual spawning migration of the 
Northeast Arctic cod, which in winter comes from the Barents Sea and the Norwegian Sea towards the Norwegian coast to spawn, mainly around the Lofoten islands. The fishery is seasonal, beginning in late January and ending in late April.

The paper unfolds as follows. In the next two sections we provide a description of the data and the industry, including descriptive statistics of labor productivity, entry into the industry, the stages of technological change seen in the industry, as well as development of prices and resource abundance. In Section 4 we conduct an extensive analysis of total factor productivity and technological change, taking the fish resource into account within a formal framework. The last section concludes.

\section{Data}

Since 1859, the year the Lofoten Law of 1857 took effect, a report on the Lofoten fishery has been published annually. These reports contain much information on the fishery and events related to it. ${ }^{2}$ Up to the 1930s the information became increasingly detailed. There are records of how many fishermen and boats participated in the fishery, from 1875 broken down on the gear types used, how much fish they caught, on byproducts such as fish liver, on prices of fish and byproducts, the weather, the number of ships coming to Lofoten to buy fish, and much else. ${ }^{3}$ After the 1930s the degree of detail in the reports declined gradually, and as of the early years of this century they are just a six page summary with a few graphs and tables, whereas in the 1930s they would run to over a hundred pages. This poses certain problems in getting long, consistent time series of variables.

The data on catches and participation in the fishery have been collected from these annual reports. The participation is based on a census of fishermen and boats at a certain date about half way through the fishing season when the fishery is close to its

\footnotetext{
${ }^{2}$ Since 1906 these reports have been published by the Directorate of Fisheries (Fiskeridirektoratet), but prior to that by its forerunner (Norges Fiskeristyrelse) and the Department of the Interior (Departementet for det Indre). All the reports are available electronically from the Institute of Marine Research, Bergen.

${ }^{3}$ From 1879 there are detailed tables on the diseases treated by the resident doctors during the fishing season, from which we can find, among other things, how many persons were treated for syphilis (the maximum was 14 in 1895, and the last case was recorded in 1952) and how many teeth were pulled (a maximum of 1346 in 1935). We can also find how many tradesmen and other professionals of various kinds traveled to Lofoten during the fishing season to offer their services. One such was quacksalvers, of whom there was a maximum of four in 1898, but none in some years, and they dropped out entirely after 1935.
} 
peak. ${ }^{4}$ Participation varies throughout the season, increasing gradually up to a peak and then falling off towards the end. It is highly likely that people left the fishery early if the fishery was not going well, and their decision to begin fishing, or whether to participate at all, is likely to have been influenced by news about how well the fishery was going. After the telegraph and, later, telephone came on the scene the fishermen had access to up-to-date news about this. The participation measures thus are imperfect in that they say nothing about the intensity of participation; clearly the fishing effort by a thousand boats over four weeks is not the same as that of eight hundred over six weeks; in fact the latter would be greater, all else equal.

The Lofoten reports contain no data on how much capital was invested in the boats, and neither do they specify the size or other physical characteristics of the boats that might be used as proxies for the capital investment. From other sources we know, however, that even if most boats were small there were considerable differences in size and equipment. Beginning in 1936, cost and earnings studies of the Lofoten fishery were carried out until the 1960s, when such studies were extended to the entire Norwegian fishing fleet. These studies reported the size distribution of the boats participating in the fishery. Over this 30-year period this did not change a great deal; the range was wide, from less than 20 to over 80 feet length, but most boats were between 20 and 50 feet. $^{5}$ Later on we will refer to some of the results from these investigations.

The data on the fish stock stretch back to 1900 and were obtained from the Institute of Marine Research in Bergen. These data are based on stock assessment models, which follow the age composition of the stock through time. Even if these methods are known to have their limits in providing up-to-date assessments of the stock, their accuracy for any given year improves as time goes by and more becomes known about the life history of the different year classes of fish. The data on the stock provide figures for the mature part (which is exploited by the Lofoten fishery) separately and are expressed in weight units. The fish mature at an age of six to seven years, and the spawning stock consists of several year classes, the oldest fish being over 10 years. The

\footnotetext{
${ }^{4}$ Before 1918 this was March 16, but March 22 from that year on.

${ }^{5}$ These reports were published in the series Årsberetning vedkommende Norges Fiskerier, and later in the journal Fiskets Gang, published by the Directorate of Fisheries (Fiskeridirektoratet), Bergen.
} 
stock data for 1900-1912 were estimated using the catch per fisherman. ${ }^{6}$ While these data undoubtedly are less than perfect, they certainly are the best ones available. There is reason to expect the more recent data to be more accurate than earlier ones, due to improvements in stock assessment methodology.

\section{The Lofoten Fishery: Background and descriptive statistics}

\subsection{Major developments}

Traditionally the Lofoten fishery was pursued with hand lines, each fisherman holding a line with a sinker and a baited hook. In the 1700s new types of fishing gear came into use; gill nets and long lines left lying in the water overnight. Originally there was much opposition to the novel gears from those who used the traditional hand line. A petition was sent to the King in Copenhagen (Norway was at that time under the King of Denmark), begging for these new gear types to be banned. The King was apparently sympathetic to the fishermen's arguments, and in 1744 he sent a letter to the governor of Nordland County, admonishing him to allow only the use of hand lines, which "since time immemorial have been used in the fishery by rich and poor alike"7 Over time the once so novel gear types became traditional and are now referred to as such, but opposition to new types of fishing gear or new technology has been a recurrent theme in the Lofoten fishery, and so have petitions to ban their use. Sometimes they have met with success, such as for seines in the latter part of the $19^{\text {th }}$ century and purse seine in the 1950s, while at other times the new technology has carried the day, such as engines in the early 1900s and Danish seine after 1959.

In 1816, after the restoration of the Norwegian state, albeit in a union with Sweden, a law on the Lofoten fishery was enacted. This law went a long way towards establishing what lately has come to be known as territorial use rights (Christy, 1983). The fishing banks were divided into areas belonging to the nearest fishing base on land and further subdivided into fields where the boats were allowed to fish. The allocation of the fishing fields was in the hands of local governing committees, usually headed by the

\footnotetext{
${ }^{6}$ For details on the data, see Hylen (2002).

${ }^{7}$ The King's letter refers to some of the arguments advanced against the new gear types. They were said to be too expensive for the common man to acquire and to cause much distress to Our Lord through encouraging the use of foul language and fights. The letter is quoted in Steen (1930), p. 30.
} 
owner of the onshore facilities which the fishermen had to rent for accommodation and for drying the fish. In practice these fishing fields became an informal property of the owner of the onshore facilities, being rented out with the base on land, with good fields carrying a premium rent (Solhaug, 1983).

Over time, dissatisfaction with these arrangements developed. One important contributing factor seems to have been a shift in fish migrations from the eastern part of Lofoten to the western part (Solhaug, 1983), but such shifts occur from time to time, presumably depending on environmental factors. Being tied to one particular fishing place impeded pursuing the fish wherever they happened to be, and in the western area there was more space and less need for a spatial regulation. This resulted in a new law on the Lofoten fishery, enacted in 1857. This law did away with the previous spatial regulation and made it clear that anyone had the right to fish wherever he wanted, but allowed for division of the fishing grounds between different gear types if deemed necessary to avoid entanglements. The new law thus established the Lofoten fishery as an open access fishery, but subject to certain rules of conduct. The law established a regulatory authority for the Lofoten fishery, whose purpose was ensuring that the rules of conduct were followed, such as not leaving harbor until the morning signal had been given, not setting any fishing gear after a certain hour in the evening, and respecting the division of the fishing areas between the various gear types.

The law of 1857 certainly resounded with the prevailing free enterprise spirit of the time. The Lofoten reports also made it quite clear that the purpose of the law was to increase the efficiency of the fishery by making it easier to follow the fish to wherever they happened to be and to allow the fishermen to use their skills and endurance to the utmost. This was long before overexploitation of fish resources had been recognized; on the contrary it was widely believed, even by prominent biologists, that fish resources were inexhaustible and that fishing made no difference whatever for their fecundity (Smith, 1994).

Over time, discontent also developed over the new law. As the number of fishermen increased, spatial control again became necessary to avoid gear collisions. The law allowed for dividing the fishing banks between different types of gear, but not between boats, and the latter arrangement apparently was not what the fishermen sought. 
Instead they sought influence over the division of ocean space between different gears and other regulatory issues, not least because of the development of new gears such as seines, which most of them wanted banned, and because of attempts by some landowners to close off certain areas where the fish concentrated and either have it all for themselves or charge fishermen for access to these areas. Yet another law was enacted in 1897, giving fishermen influence over management through consultative committees while keeping the ultimate authority and enforcement firmly in the hands of the state. This arrangement has basically prevailed until this day.

The Lofoten fishery remained an open access fishery until 1990. There were no restrictions on the number of boats, fishing time, or quantity of fish caught. ${ }^{8}$ In 1989 a limit was set for the first time on how much fish could be caught, and the fishery was stopped half way through the season when this limit had been reached. In the following years individual boat quotas or quotas for groups of boats were used, which limited the amount of fishing time at least some boats could spend in this fishery. Because of this our analysis of the fishery will end in 1988, the last year without regulations affecting fishing time and the quantity caught.

\subsection{The Lofoten fishery 1860-1988: technical change and institutional change}

In this section we will describe the development of participation, technological and institutional change taking place in different periods, as well as the development of catch and stock in the Lofoten fishery. The main aim is to identify different periods in the fishery in terms of technology and participation. Figure 2 shows the development of men, boats, catch, fish price and fish stock from 1860 until 1988. Participation in the Lofoten fishery, whether measured as number of fishermen or boats, evolved in a somewhat cyclical fashion; it was high in the 1880s and 1890s and peaked again in the 1930s. It declined sharply from the early 1950s to 1965 and continued declining after that, but at a lower rate and somewhat irregularly.

\footnotetext{
${ }^{8}$ There were a few exceptions to this. In 1981-84 the fishery was stopped in-season for about two weeks, which included the Easter holiday, during which little fishing would have taken place anyway. In the 1950s and 60s it occasionally happened that the fishery was halted for a few days or limits set on the catches of individual boats because of market problems.
} 


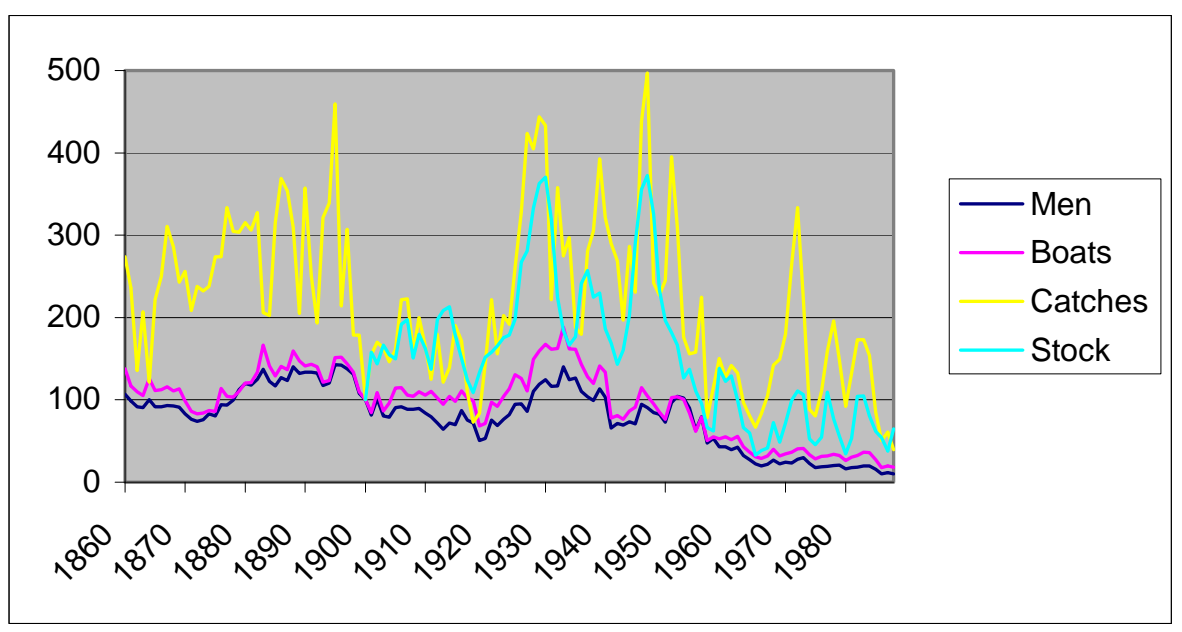

Figure 2: Fixed base indices for fish catch, the number of fishermen, fishing boats, and spawning stock in the Lofoten fishery 1860-1988. $1900=100$.

Based on Figure 2 and the somewhat scarce literature, we think five different periods can be distinguished (Brandal, 1981, 1982; Solhaug, 1983; Lefdalsnes, 1969; Iversen, 1937):

1. Until about 1880: mostly small and open boats without sail, using gill nets, long line and hand line.

2. From about 1880 to 1906: Open boats were replaced by decked boats with sail, even if many open boats remained. Decked boats were larger than the open boats. Sail boats used small boats (“dories”) for net and long line.

3. From 1906 to 1920: Motorization of the fleet. By 1920 most of the decked boats had engines. Most of the change took place from about 1912 to 1920.

4. From 1920 to about 1940: Two distinct changes occurred; (i) mass increase in the participation of open boats using hand line and long line; (ii) enactment in 1938 of a law giving fishermen monopoly of sales of fish at the first hand (the so-called Raw Fish Law).

5. From the mid- to late 1950s: the introduction of nets made of synthetic fiber, and, later, development of increasingly sophisticated jigging machines for hand lines. 
Probably also general improvement in technology proceeding in small, incremental steps.

\subsection{Participation in the fishery}

The long term changes in participation (Figure 2) are probably related to both demographic development and “outside options.” Before 1900 there was substantial immigration to Nordland County, but substantial emigration, both to the rest of the country and to America during the two decades after 1900. In the two decades 1920-1940 the emigration to America slowed to a trickle, because of restrictions in the United States, and emigration to the rest of Norway also declined because of a slowdown in industrial development and economic growth in general. ${ }^{9}$ After 1950 the Norwegian economy entered a phase of full employment and rapid economic growth, coinciding with a rapid decline in the participation in the Lofoten fishery.

The variations in participation are rather moderate compared with the fish catches, which display both short term and long term variability. Much of this variability is evidently related to variations in the fish stock. Very roughly we can identify two periods of large but variable catches, 1860 to 1900 and mid-1920s to 1950. From 1900 to the mid-1920s and after 1950 catches were much lower and less variable, except for a peak in the early 1970 s.

\subsection{Changing gear type}

Figure 3 shows the number of boats using the three traditional gear types; gill nets, long lines, and hand lines. The most conspicuous feature is the enormous bulge in the number of hand line boats from 1920 to 1965, rising from a few hundred in 1920 to over 5000 in the early 1930s and then dropping off gradually, with some fluctuations. The surge in the number of hand line boats was accompanied by an increase in the number of fishermen per boat, so for a time that number was about the same as for the long line boats (see Figure 5), while both before and after it was much lower. The increase in the number of hand line boats in the 1920s was not due to a switch of gears; the number of long line boats was also increasing while the number of gill net boats changed little. It thus appears

\footnotetext{
${ }^{9}$ On the demographic development up to 1940 and the importance of “outside options," see Vea (1988).
} 
that many owners of relatively large boats decided to participate in the Lofoten fishery in the 1920s and then gradually pulled out (or switched gear) from about 1930 onwards. The number of long line and gill net boats has also been variable, but less so, especially the gill net boats. There is some evidence of gear-switching between gill net and long-line boats up to about 1920 in that we find significantly negative correlations for some subperiods.

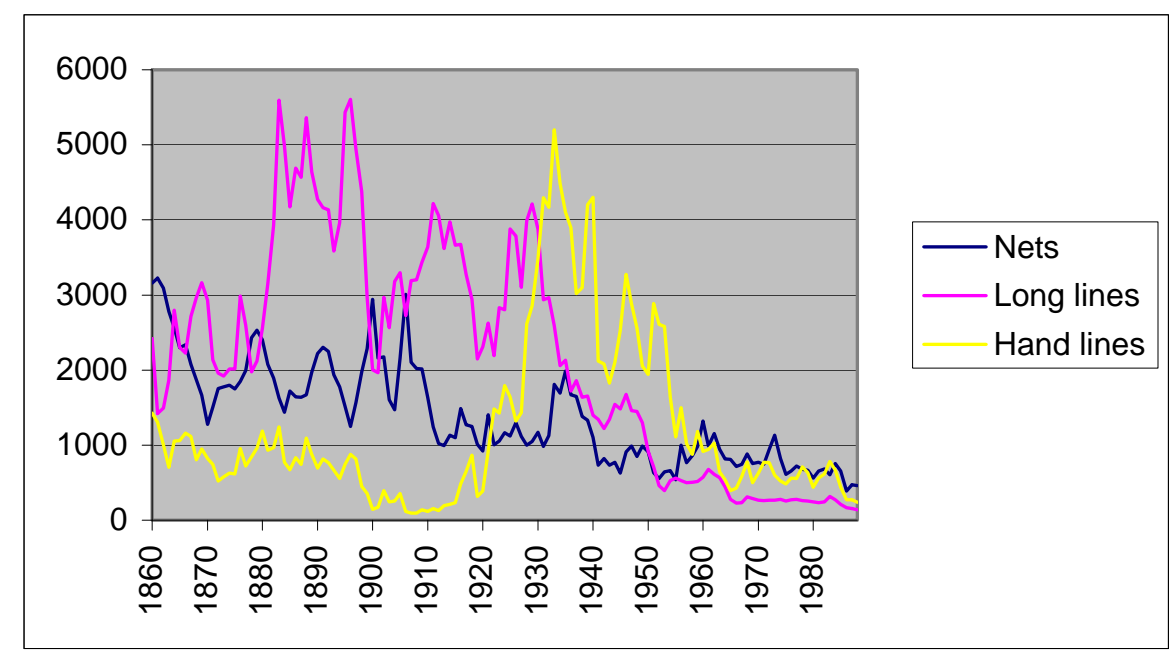

Figure 3: Number of boats using nets, hand lines and long lines.

It is very tempting to see this increase in the number of hand line boats in the 1920s as a result of poor outside opportunities together with a continuing population growth (Lefsdalsnes, 1969). The 1920s were a period of economic stagnation in Norway, and the emigration to the United States had declined substantially. Hand lines were the cheapest fishing gear available and so the poor man's choice. What is a bit surprising is that this development was to some extent reversed in the 1930s, also difficult times with few opportunities. Some of that may be due to frustrated expectations; the Lofoten reports in the 1930s make references to fishermen leaving Lofoten poorer than when they came and in need of financial help to go back home.

\subsection{Labor productivity}

Figure 4 shows the development of productivity, measured as catch volume and value per fisherman. There was surprisingly little trend in productivity until the mid-1960s, when it 
was in fact little higher in volume terms than a hundred years before. Because of the enormous inter-annual variability, moving averages provide a better basis of comparison than comparing just initial and final years. Figure 4 also shows 9-years moving averages, which give a reasonable smoothing of the curves. In volume terms, labor productivity was almost three times higher in the 1970s and 80s than in the 1860s, but in terms of real value it was 15 times greater. Given that the Norwegian economy grew impressively over the said period, fishermen would have been in dire straits indeed if rising prices had not come to the rescue.
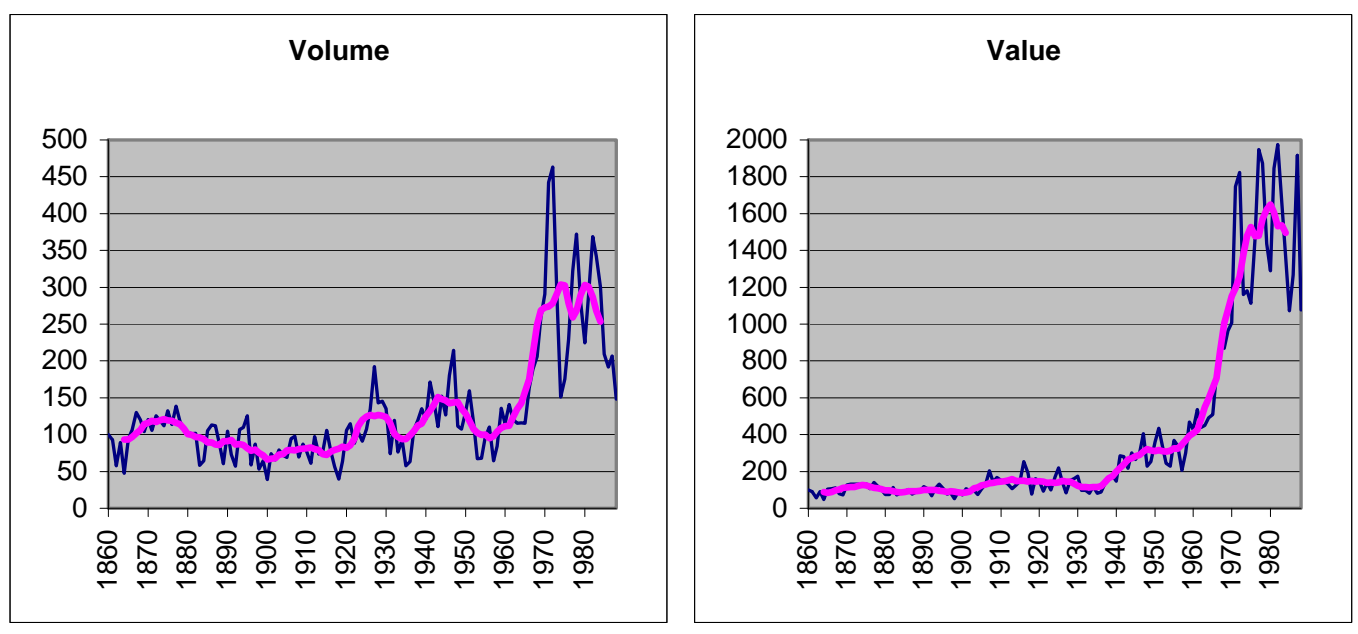

Figure 4: Fixed-base indices of productivity (catch per fisherman), in value and volume terms, annual values and 9-years moving averages. The value index is in constant value of money.

This rise in the revenue per fisherman coincides with a decline in the number of fishermen per boat, as seen from Figure 5. Another noteworthy feature is that rising prices compensated for the fall in labor productivity in the 1940s and 50s. In this period as well as later prices were regulated by the Raw Fish Marketing Board.

Even if labor productivity in volume terms remained fairly constant for a hundred years, there was some variation in the number of fishermen per boat, as is seen from Figure 5. We can identify four phases. From 1860 to about 1900 the number of fishermen per boat increased for all three gear types. In the early 1900s the number fell significantly over a relatively short period, first for gill net boats, and later for the long line and hand line boats. The Lofoten reports mention two reasons for the decline in the number of men 
per boat in gill netting in the latter half of the 1890s. First, beginning in the early 1890s, winches were gradually introduced to pull the nets. This, according to the same reports, did not result in a smaller crew until a few years later, however. Second, from 1895 a new type of net, the so-called small fish net, came into use. This required a smaller crew than the other type of net.

That winches did not immediately result in smaller crews indicates that it takes time for a technology to diffuse and for fishing firms to adjust to the new technology. We see a similar pattern in the motorization of the boats. Although first introduced around 1900, this process did not take off until about 1915, but had largely run its course in 1920, even if many open boats without engines still remained.

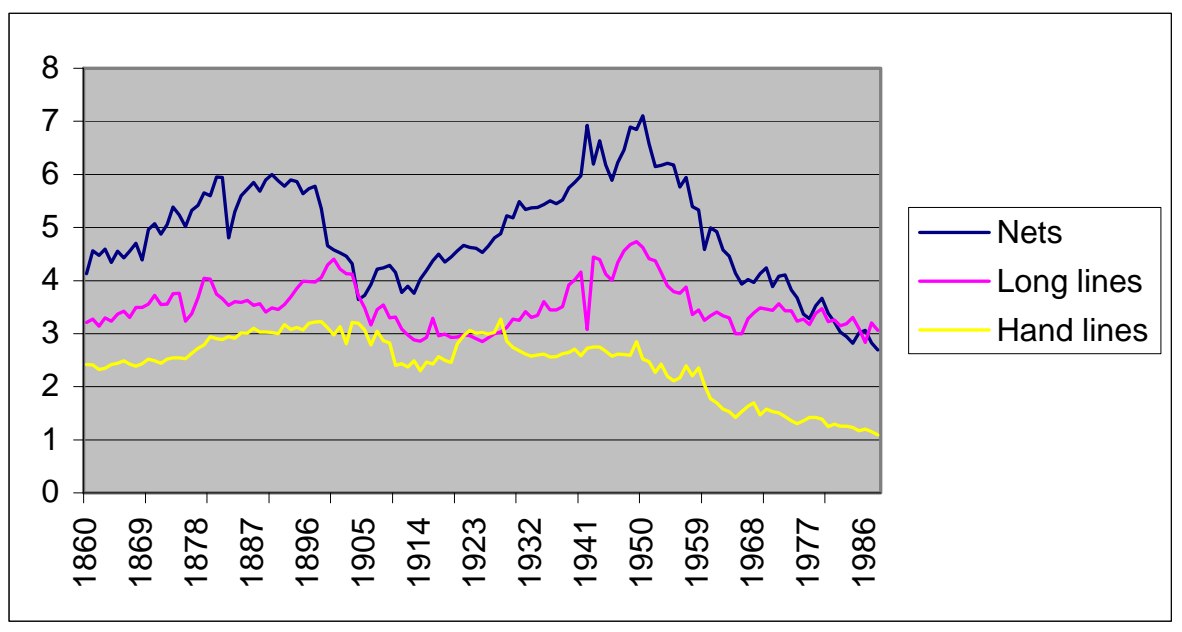

Figure 5: Fishermen per boat.

The first mention of engines in the Lofoten reports occurred in 1895, when a gill net boat was reported to have used a petroleum engine, which apparently did not work very well. Over the period 1907-1915 much of the fleet was motorized, although boats without motor would be in use for many years after that. ${ }^{10}$ This period coincided with a decline in the number of men per boat in the long line and the hand line fishery. Replacement of oars and sails by engines is therefore likely to have been labor-saving,

\footnotetext{
${ }^{10}$ That this transition was ongoing but incomplete by 1910 is clear from the Lofoten Report for that year. This was apparently not a good year, and many fishermen blamed the noise from motorized boats for having scared away the fish. The report concurred with these boats having been numerous and the noise formidable, but was otherwise out of sympathy with the complainants, considering the argument as being vicarious for arguing against competing and better equipped fishermen.
} 
although the Lofoten reports make no mention of this. Shortly after 1910 the number of men per boat began to increase again, first for the gill net boats and later for the long line and hand line boats. This could possibly be because boats propelled by engines instead of sails and oars could be made bigger, accommodating a larger crew. Then, finally, since about 1950 the number of fishermen per boat has fallen almost uniformly. This period coincides with strong economic growth and growing real wages in the Norwegian economy, which is likely to have encouraged substitution of capital for labor, but only after 1965 did labor productivity increase substantially in volume terms (Figure 4). ${ }^{11}$

\section{Productivity and fish abundance}

The main approach we use in estimating total factor productivity over time is to exploit the panel of gear types and years and estimate yearly dummies, which gives a general index of technical change (Baltagi and Griffin 1988). ${ }^{12}$ The production function with the general index of Hicks' neutral technical change is specified as

$$
\ln Y_{t}=a_{0}+a_{1} \ln L_{t}+a_{2} \ln B_{t}+b S_{t}+d_{H L}+d_{L L}+A(t) \text {, }
$$

where $L$ is the number of fishermen, $B$ the number of boats, $d_{H L}$ and $d_{L L}$ are dummies for hand line and long line respectively, and $A(t)$ denotes the general index of technical change that varies by year. Because $A(t)$ is unobserved, annual dummy variables are used instead. These yearly dummies of course primarily "explain" the annual residuals, but their evolution over time should reflect technical progress. ${ }^{13}$ This leads to the following equation to be estimated:

$$
\ln Y_{t}=a_{0}+a_{1} \ln L_{t}+a_{2} \ln B_{t}+b S_{t}+d_{H L}+d_{L L}+d_{1901}+\ldots+d_{1988}+u_{t},
$$

\footnotetext{
${ }^{11}$ The Lofoten Reports are surprisingly silent on what technical changes may have been involved. One change that apparently increased productivity, although probably not of a labor-saving kind, was the use of synthetic materials in nets and lines. This transition took place in the mid-1950s.

${ }^{12}$ We have also estimated (1) for each gear separately and get similar results for all gear types, which supports the panel approach..

${ }^{13}$ Some of the year to year variation in these residuals is undoubtedly due to variable weather conditions. The only consistent data we have on this is the number of pull days, i.e., the number of days the fishermen could pull their nets and lines. There is a statistically significant positive relationship between the yearly dummies and the number of pull days, but the effect on the dummies is very small; the curve in Figure 6 hardly changes at all.
} 
where the d's with time subscripts are coefficients of dummy variables for the years 1901-1988 (the stock data begin in 1900). The rate of technical change, given by $A(t)-A(t-1)$, allows for Hicks-neutral technical change that varies by year. Taking 1900 as the base period for $A(t)$, so that $A(1)=0$, allows identification of $a_{i}$ and the index $A(t)$. The general index of technical change is calculated as $\exp [A(t)]$ (Baltagi et al. 1995).

For comparison, we also show results of estimating (2) with a time trend (gt) but without yearly dummies. In both cases, technological change is disembodied and exogenous. Technological change with the time trend is constant Hicks neutral, while with the general index approach technological change is Hicks-neutral but not constant and is essentially a Solow residal.

Table 1: Estimates using panel data (Equation [2]). t-values in parentheses. ${ }^{*}(* *)$ significance at the $5 \%$ (1\%) level.

\begin{tabular}{|l|l|l|l|l|l|l|l|l|}
\hline & $a_{1}$ & $a_{2}$ & $b$ & $d_{H L}$ & $d_{L L}$ & $g$ & $a_{0}$ & $R^{2}$ \\
\hline Yearly & .7886 & .1718 & 1.2179 & -.9342 & .1621 & & -6.3499 & 0.94 \\
dummies & $\left(4.05^{* *}\right)$ & $(0.95)$ & $\left(5.19^{* *}\right)$ & $\left(-5.81^{* *}\right)$ & $\left(2.07^{*}\right)$ & & $\left(-4.03^{* *}\right)$ & \\
\hline Time & .6376 & .2965 & .4393 & -1.0524 & .1200 & .0233 & -1.2188 & 0.87 \\
trend & $\left(4.16^{* *}\right)$ & $\left(2.03^{*}\right)$ & $\left(5.82^{* *}\right)$ & $\left(-7.74^{* *}\right)$ & $(1.48)$ & $\left(15.91^{* *}\right)$ & $\left(-2.79^{* *}\right)$ & \\
\hline
\end{tabular}

The sum of $a_{1}$ and $a_{2}$ is close to one, implying constant returns to scale for labor and boats. They also come close to agreeing with the revenue shares of labor and capital. The cost and earnings studies of the Lofoten fishery referred to above report these revenue shares, determined by rules agreed between fishermen and the boat-owners, who often were fishermen themselves. A part of the revenues was for the boat and so a compensation for the capital equipment used, another part was shared among the fishermen, and a third part was for defraying the expenses for the fishing gear, which the fishermen sometimes provided themselves. The reports for 1936-1951 show the combined share of labor and gear, which was fairly stable at 70-75 percent. The reports 1955-1962 show all three. For these years the average combined share of labor and gear was 72, 63 and 67 percent for gill net, long line and hand line boats, respectively. A troubling difference between the two sets of results in Table 1 is the much higher value of 
$b$ obtained with the yearly dummies. Exceeding unity, this is much higher than obtained for the individual gear types. ${ }^{14}$

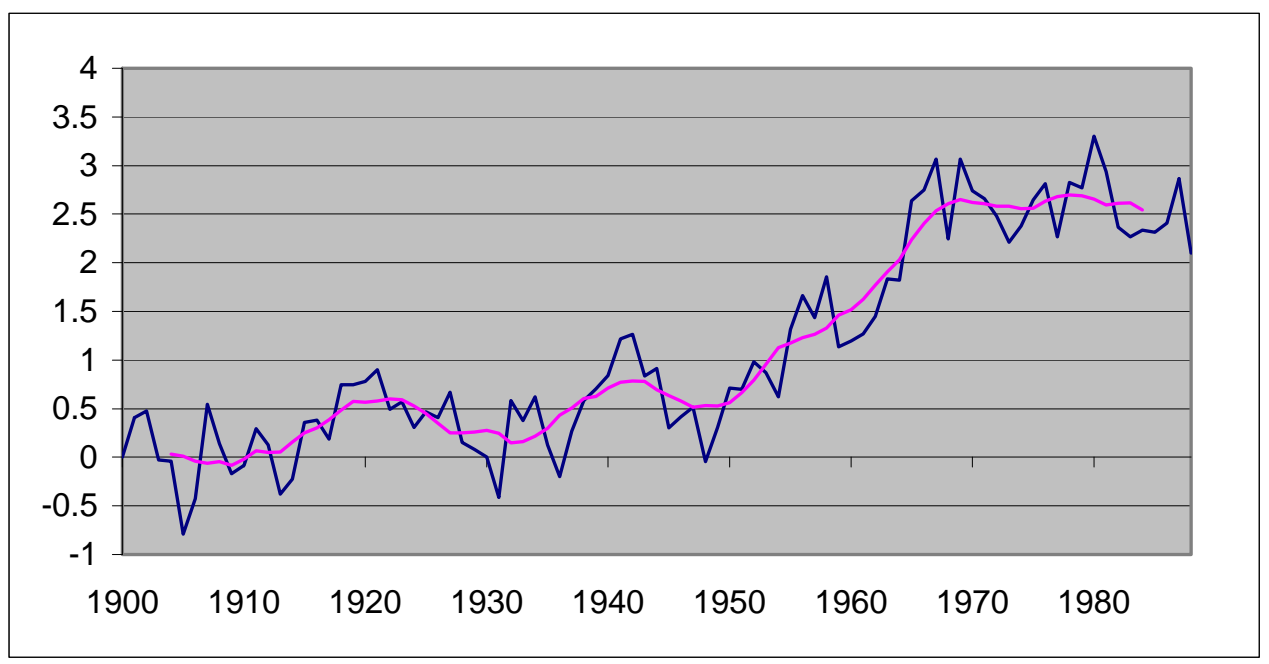

Figure 6: Estimated $d_{t}$ 's from Equation (2) and 9-years moving average.

Figure 6 shows the values of the annual dummies, as estimated by Equation (2), together with a 9-years moving average. There were substantial year-to-year fluctuations 1900-1950, but with a slowly rising trend. Then, in 1950-1970, there was a much stronger, positive trend which, smoothed over a 9-years interval, was unbroken. After 1970 there does not seem to have been any technological progress at all.

The strongly positive trend 1950-1970 can be explained by the general economic progress in Norway during this period. The boats became better equipped and fewer. It is likely that the least effective ones disappeared; this would show up as an improvement in technology. Some technological innovations were introduced in this period; the most important one was probably synthetic fibers in nets and lines. These came in the mid1950s, but the improvement in technology seems to have begun earlier than that, and these innovations, which became widespread over a period of just a few years, do not seem to have caused a rapid shift of the production function. The most surprising thing is the stagnation that appears to have occurred after 1970. It is true that synthetic fibers had become universal by then, but we would still expect to see traces of improved equipment.

\footnotetext{
${ }^{14}$ These results are not reported in this paper but are available in an earlier version published as a working paper.
} 
In particular we know that jigging machines for hand lines were introduced in the 1970s and 80 s and became more and more effective, but there is no trace to be seen of this. The technological decline that occurred in the 1920s could be due to the increased use of hand lines, earlier mentioned, and when this trend was reversed the technology improved again. The decline after 1940 could have been caused by the occupation of Norway during the Second World War and its aftermath of rationing and scarcity of foreign currency. The motorization of the fleet, which took place about 1905-20, is a likely reason for the rising productivity from shortly after 1910 to about 1920.

\section{Conclusion}

For about a hundred years labor productivity in the Lofoten fishery varied a great deal but hardly increased, while from the mid-1960s to the 1980s it almost trebled. Still, this would not have been enough to prevent the fishery from lagging behind agriculture and manufacturing; but with prices rising still more rapidly, revenues per fisherman in the end did better than keeping up with the wages in these sectors, using 1860 as a base year. Productivity in value terms (constant value of money) began to outpace physical productivity in the late 1930s, at which time price regulation was introduced. This may have resulted in higher prices, and seems to have stabilized prices, making them less dependent on the quantity caught. From the mid-1950s price subsidies were provided, which is likely to have led to higher and more stable prices. These subsidies were not eliminated until after the end of the period being analyzed here (Hannesson, 1996).

It is puzzling how the Lofoten fishery could continue for about a hundred years without any increase in productivity while wages in other sectors of the economy rose. The answer may lie in the fact that the Lofoten fishery is a seasonal fishery, combined with participation in other fisheries and agriculture. The returns from these activities may have been sufficient to justify participation in the Lofoten fishery, especially since this coincided with low activity in the other occupations. Furthermore, the Lofoten fishery provided cash income, while the farming activities with which it was combined were largely for subsistence. This may have meant an extra premium for the Lofoten fishery, even if the results were meager. Many fishermen did, however, combine the Lofoten fishery with other fisheries which also provided cash income. 
From the early 1950s the participation in the Lofoten fishery, both in terms of the number of fishermen and the number of boats, fell steeply. This was a time when the Norwegian economy reached full employment and attained a high rate of economic growth. In the mid-1960s and possibly earlier, productivity (in value terms) in the Lofoten fishery began to outpace wages in agriculture and manufacturing, and from the mid-1960s the decline in the participation in the Lofoten fishery was slowed considerably, but not reversed. The productivity improvement in the Lofoten fishery was largely due to rising prices; in terms of volume it still lagged behind wages in agriculture and manufacturing. It is possible to argue that the rise in prices soothed the impact of open access and kept people in the fishery to a greater extent than warranted.

Total factor productivity has risen faster than labor productivity in the Lofoten fishery. While the technological progress in the fishery has probably been comparable to other industries in the long term, even if it has been uneven over time, it has to some extent been neutralized by a decline in the fish stock. This decline would have prevented the Lofoten fishermen from reaping the full benefits of technological progress, but rising prices came to the rescue.

It is tempting to ascribe this discrepancy between the development in total factor productivity and labor productivity to the classic open access curse. As discussed above, the Lofoten Law of 1857 established the Lofoten fishery as an open access one and did away with whatever exclusive use rights that had developed in the fishery prior to that time. Improving the lot of fishermen was the most likely intention; this was well before the concept of biological overfishing had been generally recognized, and the science of fisheries biology was yet to be developed. ${ }^{15}$ In the longer term, however, this may have been self-defeating through encouraging excessive participation in the fishery and exposing it to the familiar evils of open access. There are three types of problems caused by open access that we may identify for the purpose of this discussion:

(i) excessive fishing, leading to a diminishing fish stock and lower future returns;

(ii) overcrowding on the fishing banks, with one fisherman's gear taking fish that another could have taken later in the season;

\footnotetext{
${ }^{15}$ The history of the science of fisheries biology is told in Smith (1994).
} 
overcrowding so that one fisherman's gear intervenes directly with another's, for example through entanglements.

As to the first effect, this was most likely present to some extent. The mature part of the cod stock consists of several year classes of fish. Increased fishing effort in any one year lowers the survival rate of the year classes, which reduces the stock of fish available in later years. The number of boats and fishermen was at its highest in the two decades before 1900 and again in the 1920s and 30s, and so the stock externality is likely to have been most prominent in those years. These were also periods of declining productivity, preceded by a period of higher productivity that may have called forth greater fishing effort. But each year the mature stock is replenished with new cohorts. This was increasingly determined by what was left over by the ocean fisheries that developed over the last century and mainly fished young, immature fish. Until the early 1930s the catches in the Lofoten fishery were in some years almost one half of the catches of the Northeast Arctic cod, but after 1950 they seldom exceeded 10 percent. As the $20^{\text {th }}$ century proceeded, the decline in the fish stock available for the Lofoten fishery was increasingly due to a rising fishing pressure in the offshore fisheries.

The Lofoten reports in the 1930s make repeated references to excessive participation in the fishery, alleging that the revenues per fisherman would most likely improve if there were fewer of them. It was never made explicit exactly why this would happen: there is no reference to a "dynamic stock externality" by which excessive fishing in one year would reduce the catches in the coming years. By the 1930s it was certainly well known that the Lofoten fishery was based on several year classes, and that the survival rate of the fish to a large extent determined how much would be available the next year; in fact, there are supplementary chapters on this in many of the annual reports in the 1930s and even earlier, contributed by fisheries biologists. It is likely, however, that those who penned the annual reports had in mind problems Two and Three above, i.e., conflict between gears or gear types on the fishing banks, which increasingly had to be divided between different gear types to avoid conflicts, and fish being caught early in the season instead of being available later if there had been fewer fishermen and boats. With respect to the latter, it does not seem to have been serious enough to affect the time pattern of landings. 
In the difficult years of the 1930s, new and more productive technology was the solution envisaged in the Lofoten reports. Experimenting with new types of gear had a long history in the Lofoten fishery, and so did the opposition to any such or other novelty. The opposition in the 1700s to gill nets and long line was mentioned earlier. The Lofoten reports in the 1800s inform that some fishermen believed that the underwater telegraph cables killed the fish; dead fish were reported to be deposited along the tracks of these cables (how did people know?). The report writers in the 1800s promoted scheduled calls by steamships to outlying parts of Lofoten during the fishing season, but some fishermen thought this would scare the fish away. As the boats became equipped with engines, the sound from these was alleged to do so. Experiments with seines were made in the late 1800s, but in the 1890s all seines were banned from Lofoten, due to pressure from fishermen. From the 1920s on government-financed experiments with various types of seines took place, and around 1950 the Lofoten reports were enthusiastic about the purse seine. In 1950 this gear began to be used on an appreciable scale, but it took only a couple of years for the reports to express great doubts about this. The fishermen using the "traditional" gear saw it as a threat, in the spirit of their forerunners in the 1700s who felt the same way about gill nets and long lines. The purse seine took up a lot of space, and it was quite effective, threatening to make a large number of fishermen redundant. In 1958 it was outlawed.

The "long waves" in participation in the Lofoten fishery are consistent with the role of an open access fishery as livelihood of last resort, where people enter or exit as a result of demographic pressures or rise and falls in outside options. The immigration to Nordland County before 1900 was accompanied by increasing participation in the fishery, the emigration, both to America and to the rest of the country, coincided with a decline in participation, and participation in the fishery reached new heights as emigration, both to America and the rest of the country, more or less came to an end in the 1920s and 30s. Then, as the Norwegian economy entered the era of full employment and economic growth after the Second World War, participation in the fishery declined, especially as regards the number of fishermen, and labor productivity in the fishery rose.

The history of the Lofoten fishery has a familiar ring to it; this is not unlike the situation in the fisheries of many of the world's poor countries today. For a long time the 
Lofoten fishery played the role of employment opportunity of last resort; when times were bad people had resort to it, because of its open access character. There was political pressure from fishermen to keep things that way, and pressure to ban new technologies that would save labor in the fishery and would be expensive for fishermen to acquire. Open access and prohibition of some efficient technologies (but not all) may have succeeded in distributing incomes more widely, but one may ask whether increased participation led to lower returns and only succeeded in distributing poverty more widely. Banning more efficient technologies and the development of access rights in suitable localities is certainly likely to have meant foregoing increases in productivity.

And as times got better, the exodus began. Productivity improved, partly through technological improvement but probably because of less participation as well. The productivity improvement may well have been self-enhancing, due to a positive feedback on technology; new technology is typically expensive and its returns uncertain, so poor fishermen are unlikely to introduce it, as is also abundantly clear from the opposition to new methods that always has come from the less well-off fishermen. 


\section{REFERENCES}

Baltagi, B. and J. Griffin (1988). A General Index of Technical Change. Journal of Political Economy 96(1): 20-41.

Baltagi, B., J. Griffin, and D. Rich (1995). The Measurement of Firm-Specific Indexes of Technical Change. Review of Economics and Statistics 77(4): 654-663.

Brandal, Trygve (1982). Den norske fiskeflåtens utvikling ca 1889-1940. Hovedliner og kjeldedekning. Historisk Tidsskrift.

Brandal, Trygve (1981). Frå fjørestein til fjerne farvatn. Fiske og fangst i Hareid og Ulstein ca. 1880-1920. Hovedoppgave, Universitetet i Bergen.

Christy, Francis T., Jr. (1983): Territorial Use Rights in Fisheries: Definitions and Conditions. FAO Fisheries Technical Paper No. 227, Rome.

Clark, Gregory (2007). Farewell to Alms. Princeton University Press.

Gerhardsen, Gerhard Meidell (1946). Våre Fiskerier: Mellomkrigstiden, John Griegs Forlag, Bergen.

Hannesson, R. (1996): Fisheries Mismanagement. Blackwell, Oxford.

Hylen, A. (2002): Fluctuations in abundance of Northeast Arctic cod during the 20th century. ICES Mar. Sci. Symp. 215: 543-550.

Iversen, T. (1937): Utviklingen av fiske og fiskemetoder i Norge. Arsberetning vedkommende Norges Fiskerier 1937, No. 4. Directorate of Fisheries, Bergen.

Johansen, Karl Egil (1999). Moderniseringa av norsk fiske ca 1880-1920. Årbok 1999, Norges Fiskerimuseum. 
Martinussen, Atle Ove (2006). Nylon Fever: Technological Innovation, Diffusion and Control in Norwegian Fishery during the 1950s. MAST 5(1), 29-44.

Mathisen, Magnus S. (1981). Omlegging til motor i fiskeflåten i Rødøy 1900-1920. Hovedoppgave, Universitet i Tromsø.

Smith, T. (1994): Scaling Fisheries. Cambridge University Press, Cambridge, UK.

Solhaug, T. (1983): De norske fiskeriers historie 1815-1880. 2nd Ed., Universitetsforlaget, Oslo.

Steen, S. (1930): Det norske folks liv og historie gjennom tidene, Vol. V. Oslo.

Vea, J. (1981): Folkevekst og folkeflytting i Nordland ca. 1865-1940. Mimeo. Høyskolesenteret i Nordland, Bodø.

Vea, J. (1984): Motoriseringen av fiskeflåten i Nordland ca. 1905 - 1940 med scerlig henblikk på utviklingen i ytre Vest-Lofoten. NDH-rapport 1984:4. Nordland Distriktshøyskole, Bodø. 